\title{
SALIB DAN DEFINISI KEMBALI MONOTEISME YAHUDI DALAM PEMIKIRAN RASUL PAULUS
}

\author{
Brury Eko Saputra
}

\begin{abstract}
Abstraksi: Artikel ini berusaha menelusuri pengaruh peristiwa penyaliban Yesus Kristus terhadap cara Paulus membaca Kitab Suci dan tradisinya. Tulisan ini mengungkapkan bahwa salib memiliki peranan yang sangat penting dalam mendefinisikan kembali konsep monoteisme serta ramifikasinya dalam pemikiran Paulus. Dalam melakukannya, tulisan ini akan melakukan eksplorasi terhadap monoteisme Yahudi di periode tersebut dan kemudian menyajikan definisi kembali versi Paulus.
\end{abstract}

Kata-kata Kunci: Shema, Perjanjian dan Pemilihan, Definisi Kembali, Teologi Paulus

Abstract: This article attemtps to explore the influence of the cross over Paul's ways of reading the Scripture and traditions. It argues that the cross plays a significant role in redefining Paul's view of monotheism and its ramifications (e.g. covenant, eschatology, the Shema). In doing so, the article will explore Jewish monotheism of the period and then present Paul's redefinition of it.

Keywords: Shema, Covenant and Election, Redefinition, Pauline Theology

\section{Peristiwa Penyaliban dan Paulus}

Dalam 1 Korintus 1:23 Rasul Paulus berkata, "Akan tetapi, kami memberitakan Kristus yang disalibkan, yang bagi orangorang Yahudi sebuah batu sandungan, dan bagi orang-orang bukan 
Yahudi, kebodohan." Perkataan tersebut menjadi jendela bagi pembaca modern untuk memahami cara pandang masyarakat di abad pertama terhadap fenomena penyaliban. Menariknya, meskipun salib dipandang dengan sangat negatif di abad pertama, Paulus tidak pernah menghindari fakta bahwa Yesus Kristus mati di atas kayu salib (bdk. 1 Korintus 2:2; 8; Filipi 2; Roma 5-6; Galatia 3). Sebaliknya, Paulus justru berbicara pentingnya peristiwa salib di dalam sejarah keselamatan. Pemberitaan tentang salib merupakan cara Allah menunjukkan lemahnya hikmat dunia untuk memahami rencana Allah yang besar. ${ }^{1}$ Pentingnya peristiwa penyaliban juga membuat Paulus membaca kembali Kitab Suci dan tradisi Yahudi dengan kaca mata yang berbeda. ${ }^{2}$ Sejauh ini, pembaca yang teliti dapat mempertanyakan cara Paulus membaca beberapa konsep utama dalam Yudaisme, seperti monoteisme, covenant, dan penebusan dari sudut pandang peristiwa penyaliban. Apa hasil dari pembacaan yang seperti itu?

Tulisan ini akan berusaha menelusuri beberapa pertanyaan di atas. Pertama-tama, penulis berusaha memaparkan pemahaman monoteisme dalam Yudaisme sebagaimana diwarisi oleh Paulus, serta orang Yahudi pada umumnya-seperti golongan Farisi. Kemudian, tulisan ini akan mengeksplorasi relasi antara peristiwa penyaliban dengan konsep monoteisme Yahudi sebagaimana dapat ditemukan dalam surat-surat Paulus. Penulis berpendapat bahwa proses Paulus menafsirkan kembali keyakinan Yahudinya dengan

\footnotetext{
${ }^{1}$ R. David Nelson, "The Word of the Cross and Christian Theology: Paul's Theological Temperament for Today," Theology Today, Vol. 75 (1) 2018: 64. Di dalam keseluruhan artikelnya, Nelson tidak sedang menawarkan cara baca baru tentang Salib dalam pemikiran Paulus. Ia juga tidak sedang merekontruksi sebuah teologi tentang salib untuk masa kini. Artikel ini fokus pada isu bahwa salib harus menjadi inspirasi untuk mereformulasi teologi di masa kini, sebagaimana salib menjadi inspirasi (basis, kritik, dan hakim) bagi Paulus untuk berteologi.

${ }^{2}$ Lihat buku Francis Watson: Paul and the Hermeneutics of Faith $2^{\text {nd }}$ Ed., (London: T \& T Clark 2015).
} 
kacamata salib dapat disebut sebagai "definisi kembali" karena pembacaan Paulus terhadap tradisinya lebih dari sekadar mutasi pemikiran, tetapi merupakan sebuah pengalaman yang bersifat revelatoris. Dalam terang penyataan Kristus, Paulus mendefinisikan kembali pokok-pokok Kitab Suci dan tradisinya. Dalam tulisan ini, penulis akan mencoba menelusuri tiga aspek penting dalam monoteisme Yahudi yang mengalami proses definisi kembali dalam pemikiran Paulus, yaitu covenant, eskatologi, dan Shema.

\section{Monoteisme Yahudi}

N. T. Wright berpendapat bahwa monoteisme bukanlah sebuah sistem ekslusif milik orang Yahudi semata. Ada banyak sistem kepercayaan memiliki kemiripan dengan monoteisme, seperti Stoisisme, Epikurainisme, dan lain sebagainya. ${ }^{3}$ Meskipun demikian, tidak sulit membedakan monoteisme Yahudi dari monoteisme dalam tradisi atau sistem kepercayaan lainnya. Monoteisme Yahudi fokus pada konsep penciptaan dan pemilihan yang Allah kerjakan. ${ }^{4}$ Menurut bangsa Yahudi, Allah yang mereka percayai sebagai Allah yang esa adalah pencipta alam semesta (bdk. Kejadian 1-2; Mazmur 8; Keluaran 20:11; Ulangan 4:32; dan sebagainya); Allah yang sama juga telah mengikatkan diri dengan mereka melalui pemilihan dan perjanjian (covenant) yang kekal (bdk. Kejadian 12; 15; 50; Keluaran 3-4; Ulangan 4:32-39; dan sebagainya). Wright menyebut monoteisme semacam ini sebagai creational dan covenantal monotheism. ${ }^{5}$ Dengan keyakinan bahwa Allah pencipta alam semesta adalah Allah yang mengikatkan diri

\footnotetext{
${ }^{3}$ N. T. Wright, Paul in Fresh Perspective (Minneapolis: Fortress Press, 2009), 86.

${ }^{4}$ N. T. Wright, The New Testament and The People of God (London: SPCK, 1992), 244-7; Richard Bauckham, Jesus and the God of Israel (Grand Rapids: William B. Eerdmans Publishing, 2008), 7-11.

${ }^{5}$ Wright, The New Testament, 248-52; Paul in Fresh, 86; Paul and the Faithfulness of God (Minneapolis: Fortress Press, 2013), 619-43.
} 
dengan mereka, bangsa Yahudi percaya bahwa Allah akan senantiasa melindungi dan menyertai mereka. Dalam hal ini, monoteisme tidak hanya menjadi suatu sistem kepercayaan, tetapi penanda identitas mereka sebagai umat Allah.

Pada masa pembuangan, monoteisme Yahudi menghadapi tantangan yang sangat berat. Tantangan tersebut datang dari penindasan yang mereka alami. Pertanyaan yang sering muncul di era ini adalah: jika Allah berkuasa atas alam semesta, mengapa ada banyak penderitaan yang harus dihadapi bangsa Israel? Jika Israel adalah umat Allah, mengapa mereka perlu mengalami penindasan dari bangsa asing? Pertanyaan-pertanyaan semacam ini mendorong bangsa Israel untuk melakukan refleksi dan menyimpulkan bahwa dosa-dosa merekalah yang mendatangkan penderitaan tersebut. Sederhananya, seperti dikatakan oleh Wright, penderitaan (atau bahkan evil) muncul karena persoalan ketidaksetiaan kepada Allah-atau kegagalan manusia untuk merefleksikan rupa Allah yang sejati. ${ }^{6}$ Untuk menghadapi persoalan ini, bangsa Israel yakin bahwa mereka harus bertobat dan berbalik kepada Allah merekaAllah yang telah memilih mereka. Respons untuk bertobat dan berbalik melahirkan tradisi apokaliptik dalam memahami monoteisme Yahudi. Di dalam teks-teks apokaliptik, keutamaan Taurat dinyatakan sebagai penuntun bagi umat Allah supaya dapat menghidupi kehendak Allah dengan setia hingga Allah mengintervensi sejarah dan pada akhirnya menyelamatkan mereka (lih. Yehezkiel 3, 18; Apocalypse of Abraham 29-31; dan sebagainya). Tradisi ini juga menekankan kembali pentingnya figur seorang mesias yang akan dikirim oleh Allah untuk memebaskan mereka (lih. Daniel 7; Song of Moses; Zakharia 6; 1QH; 4Q285; 4Q369; dan sebagainya).

\footnotetext{
${ }^{6}$ Wright, Paul in Fresh, 88; Paul and the Faithfulness, 1043-61.
} 
Di masa Paulus, monoteisme Yahudi menjadi pemersatu bagi kelompok-kelompok Yahudi yang bermunculan di era tersebut (setidaknya menurut Yosephus [War 2:119-166; Ant. 13:171-173; 18:11-23], ada empat golongan dalam Yudaisme saat itu). Pemahaman ini juga yang mendorong orang Yahudi untuk menaati Taurat, terus mengharapkan kedatangan mesias yang akan dikirim Allah, serta menolak keras perintah (atau anjuran) untuk menyembah kaisar ataupun dewa-dewa Romawi. Dengan melakukan hal-hal tersebut, mereka yakin bahwa Allah akan segera mengintervensi sejarah serta membebaskan mereka dari penjajahan bangsa asing. Pemahaman ini juga membuat orang Yahudi menganggap bahwa Yahudi Kristen telah menyimpang dari iman monoteis mereka dengan memercayai Yesus sebagai Allah. Dalam surat-suratnya, Paulus memberikan informasi bahwa sebelum ia menjadi Kristen, ia memiliki dorong yang kuat untuk menghentikan praktek penyembahan terhadap Yesus oleh kelompok Yahudi Kristen (lih. Filipi 3:6; Galatia 1:13-14). ${ }^{7}$

\section{Penyaliban dan Monoteisme dalam Pemikiran Paulus}

Di dalam tulisan-tulisannya, setiap pembaca yang teliti dapat menemukan fakta bahwa Paulus tidak pernah meninggalkan iman monoteisnya setelah perjumpaannya dengan Yesus. Sebaliknya, ia kerap kali tampak sangat menekankan konsep monoteisme dalam surat-suratnya (bdk. 1 Korintus 8:6; Roma 3:29; Galatia 3:20; dan sebagainya), meskipun dengan penekanan yang berbeda dari orang Yahudi umumnya di masa itu. Apa yang menyebabkan keunikan semacam ini? Paling tidak, keunikan tersebut terkait dengan dua hal. Pertama, natur monoteisme Yahudi di masa itu memang sangat ketat, tetapi juga fleksibel. Artinya, sebagaimana diungkapkan oleh Larry Hurtado, monoteisme Yahudi kerap kali mengalami

\footnotetext{
${ }^{7}$ Larry Hurtado, "Paul's Christology." in The Cambridge companion to St. Paul, ed. James Dunn (Cambridge: Cambridge University Press 2003), 187-190.
} 
formulasi ulang sepanjang sejarah Yudaisme. ${ }^{8}$ Salah satu contoh yang baik tentang hal ini adalah munculnya "figur-figur antara" (intermediary figures), khususnya di era paska pembuangan; figurfigur tersebut sangat dihormati oleh orang Yahudi. ${ }^{9}$ Kedua, kehadiran figur Yesus (bdk. 1 Korintus 8:6) membuat Paulus memformulasikan kembali keyakinan monoteismenya. ${ }^{10}$ Beberapa ahli menyebut konsep monoteisme semacam ini sebagai Christological Monotheism. ${ }^{11}$

Dalam bagian ini penulis akan melakukan eksplorasi terhadap definisi kembali konsep monoteisme Paulus, serta ramifikasinya, dalam terang figur Yesus-khususnya momen penyalibannya.

\section{Definisi Kembali Konsep Covenant dan Election}

Sebagaimana telah dijelaskan sebelumnya, monoteisme Yahudi berhubungan erat dengan konsep perjanjian (covenant). Penetapan perjanjian dilakukan pertama kali melalui panggilan dan pemilihan Allah atas Abraham (lih. Kejadian 12). Di dalam perjanjian tersebut, Allah memerintahkan Abraham beserta keturunannya untuk menjalankan sunat sebagai tanda perjanjian yang melekat sampai generasi selanjutnya. Selanjutnya, perjanjian antara Allah dan umat-Nya juga terlihat dari hak istimewa untuk memiliki Taurat (lih. Keluaran 20; bdk. Roma 2:13, 17; 3: 1-2; dan

\footnotetext{
${ }^{8}$ Larry Hurtado, How on Earth did Jesus Become a God?: Historical Questions About Earliest Devotion to Jesus (Grand Rapids: William B. Eerdmans Publishing, 2005), 115-6; bdk. James D. G. Dunn, Did the First Christians Worship Jesus?: The New Testament Evidence (Louisville: Westminster John Knox Press, 2010.), 66-90.

${ }^{9}$ Larry Hurtado, One God, one Lord: Early Christian Devotion and Ancient Jewish Monotheism (London : SCM Press, 1988), 41-92.

${ }^{10}$ Larry Hurtado menyebut monoteisme jenis ini sebagai binitarian monotheism, lih.: Larry Hurtado, "Paul's Christology." in The Cambridge companion to St. Paul (Cambridge: Cambridge University Press 2003), 187.

${ }^{11}$ Untuk survey terkini tentang pembahasan tema ini, lih. Brandon D. Smith, "What Christ Does, God Does: Surveying Recent Scholarship on Christological Monotheism," in Currents in Biblical Research, Vol. 17(2) 2019: 184- 208.
} 
sebagainya). Kedua penanda perjanjian ini dijadikan syarat bagi seseorang untuk menjadi bagian dari Israel-umat pilihan Allah. Teks-teks seperti Joseph and Aseneth; 4 Maccabees; Yosephus; Philo; dan sebagainya sangat menekankan pentingnya kedua hal tersebut sebagai syarat. Bahkan, teks sektarian seperti Damascus Document (DC) juga memberikan tekanan khusus pada praktek sunat. Di dalam DC 16:6 tertulis dengan jelas bahwa sunat yang diterima oleh Abraham adalah bukti dari kedewasaan relasi Abraham dengan Allah. Di bagian lain, seperti DC 4:21-5:1, 8-11, dicatatkan bahwa Taurat adalah dasar etis bagi umat Allah untuk hidup berkenaan di hadapan Allah sebagai umat perjanjian. Inilah yang menyebabkan setiap anggota komunitas Qumran wajib membaca Taurat secara publik sebagaimana tercatat dalam 4Q267 frag. 5, col. 3. Di dalam surat-suratnya, Paulus memberikan informasi bahwa setiap orang Yahudi bangga dengan sunat yang mereka terima (lih. Filipi 3:4-6; Roma 9:4; dan sebagainya).

Di dalam Roma 9:4, pembaca surat Roma mendapatkan informasi bahwa Paulus tidak menolak realita bahwa perjanjian (covenant) antara Allah dan manusia mulanya diwujudnyatakan melalui pemilihan Allah atas bangsa Israel. Meskipun demikian, tampaknya Paulus mendefinisikan kembali identitas "Israel sejati" dengan menggunakan peristiwa penyaliban sebagai tolak ukurnya (bdk. Roma 2:29). Bagi Paulus, Israel sejati tidak lagi ditentukan oleh sunat dan Taurat, tetapi kematian sang Mesias di atas kayu salib. Peristiwa dalam Galatia 2:11-21 dapat menjadi jendela bagi pemikiran Paulus tentang definisi kembali ini. Di dalam teks tersebut Paulus menyinggung perdebatannya dengan Petrus tentang meja perjamuan di Antiokhia. Menurut Wright, persoalan utama di Anthiokia adalah persoalan definisi kembali tentang siapakah Israel sejati. $^{12}$ Bagi Paulus, Israel sejati bukan hanya seorang Yahudi secara lahiriah (Galatia 2:14), tetapi setiap orang yang ikut

${ }^{12}$ Wright, Paul in Fresh, 111; bdk. Paul and the Faithfulness, 783-95 
"tersalibkan" bersama dengan Kristus (Galatia 2:15-16, 19-20). Dengan demikian, bagi Paulus, keanggotaan sebagai umat Allah tidak lagi dibatasi secara fisik-terlahir sebagai Yahudi, disahkan dengan sunat dan setia pada Taurat-tetapi secara spiritual setiap orang yang ikut mati dan hidup bersama dengan Kristus. ${ }^{13}$ Inilah alasan mengapa Paulus tidak menyunatkan Titus yang adalah seorang Yunani (Galatia 2:3), padahal dalam kasus lain, Paulus bersikeras untuk menyunatkan Timotius-seorang anak dari wanita Yahudi dan pria Yunani (Kisah Para Rasul 16:2-3). Lebih lanjut, Paulus menjelaskan bahwa penyaliban Yesus harus dipandang sebagai anugerah dari Allah (Galatia 2:21). Setiap orang yang telah menerima anugerah tersebut akan dibenarkan oleh Allah karena Taurat sendiri tidak memiliki kemampuan untuk memberikan pembenaran yang sempurna (Galatia 2:21; bdk. Galatia 3:1-6). Fakta bahwa Kristus yang tersalib adalah tanda perjanjian yang baru dijelaskan oleh Paulus dalam Galatia 3-4. Di dalam Galatia 4:21-31 Paulus menggunakan kisah Sarah dan Hagar untuk menjelaskan bahwa pemilihan (election) tidak berdasarkan pada aspek lahiriah, tetapi anugerah Allah. Singkatnya, Paulus hendak mengingatkan jemaat Galatia bahwa keanggotan mereka sebagai umat Allah adalah karena relasi mereka dengan Kristus yang telah tersalib itu (Galatia 4:31; 6:14-16; bdk. Efesus 2, 1 Kor. 8:6). ${ }^{14}$

Definisi kembali terhadap konsep perjanjian dan pemilihan dalam pemikiran Paulus juga dapat ditemukan dalam Roma 3-4; 9.

\footnotetext{
${ }^{13}$ Larry Hurtado, Lord Jesus Christ: Devotion to Jesus in Earliest Christianity (Grand Rapids: William B. Eerdmans, 2003), 130-1.

${ }^{14}$ Dalam pembacaannya terhadap 1 Korintus 8:6, Andrey Romanov berpendapat bahwa kata $\dot{\eta} \mu \varepsilon \tilde{c} / \hat{\eta} \mu \tilde{v} v$ tidak merujuk pada setiap orang yang ada di komunitas

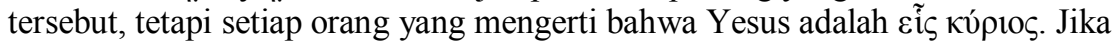
pembacaan ini benar, maka dalam 1 Korintus 8:6, Paulus sedang melakukan definisi kembali terhadap umat Allah melalui relasi dengan Yesus Kristus. Lih.

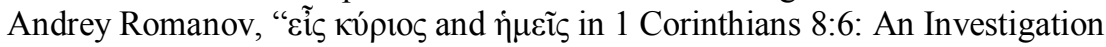
of the First Person Plural in Light of the Lordship of Jesus Christ," in Neotestamentica, Vol. 49, (1) 2015: 47-74.
} 
Meskipun Paulus menggunakan kisah yang sama dengan Galatia 4:21-31, tentang Sarah dan Hagar, Roma 4 memberikan sebuah pesan yang lebih kuat. Dalam Galatia 2:21-31 Paulus membahas hanya Ishak dan Ismael untuk menekankan aspek pemilihan Allah yang berdasarkan anugerah semata. Dalam Roma 4 Paulus bahkan menunjukkan bahwa pemilihan Abraham sendiri adalah karena anugerah Allah, bukan karena sunat ataupun Taurat (Roma 4:2, 912). Sejalan dengan hal tersebut, setiap orang yang hendak diperhitungkan dalam perjanjian seperti Abraham harus juga hidup seperti Abraham (Roma 4:22-25; 3:25). Kisah tentang Abraham dan keturunannya muncul lagi di Roma 9:6-13. Berbeda dari Galatia 2 dan Roma 4, kisah dalam Roma 9:6-13 memasukkan tokoh Yakub (anak bungsu Ishak) dalam kisah tersebut. Dipilihnya Yakub daripada Esau menekankan sebuah poin yang sangat penting tentang pemilihan Allah, di mana tidak seperti Ishak dan Ismael dengan ibu yang berbeda (Galatia 2), Yakub dipilih Allah meskipun anak bungsu dari ayah dan ibu yang sama. Hal ini menekankan kembali aspek anugerah dalam pemilihan Allah. Jika dibaca dalam konteks logis Roma 9-11, ayat-ayat tersebut befungsi menguatkan ide bahwa Israel sejati tidak ditentukan oleh aspek lahiriah, tetapi anugerah Allah. Anugerah Allah tersebut telah nyata dalam peristiwa penyaliban Kristus. ${ }^{15}$

\section{Definisi Kembali Masa Depan (Eskatologi) Umat Allah}

Bagi bangsa Yahudi di abad pertama, janji pembebasan dari Allah menjadi sebuah pengharapan yang sangat penting karena penindasan dan penjajahan yang mereka alami. Kisah tentang keluarnya nenek moyang mereka dari Mesir dan pembuangan menjadi kisah historis yang direnungkan dengan sangat serius di masa ini. Hal ini menunjukkan bahwa mereka tidak kehilangan harapan, meskipun dalam keadaan yang sangat berat. Paling tidak,

${ }^{15}$ Bdk. Charles B. Cousar, A Theology of The Cross: The Death of Jesus in The Pauline Letters (Minneapolis: Fortress, 1990), 111-21. 
ada dua cara mereka mengekspresikan harapan mereka kepada Allah. Pertama, beberapa kalangan yakin bahwa Allah akan mengirimkan utusan-Nya (mesias) untuk menyelamatkan mereka dari perbudakan tersebut. Utusan ini akan berperang mewakili Allah demi kebaikan umat-Nya. Harapan ini tidak hanya dapat dilihat dalam catatan War Scrolls dan kitab Makabe, tetapi juga berbagai pemberontakan yang terjadi di era itu, seperti pemberontakan Makabe dan perang tahun 66. Kedua, ada beberapa kalangan yang percaya bahwa pembebasan akan datang setelah adanya penderitaan besar melanda umat Allah (bdk. Ass. Mos. 910; 1 Enoch 47:1-4). ${ }^{16}$ Kalangan ini menantikan intervensi Allah dengan penuh kesabaran sambil mempelajari Taurat sebagaimana diperintahkan oleh Allah. Meskipun tampaknya bertolak belakang, kedua ekspresi tersebut merujuk pada pengharapan yang sama, yaitu Allah akan membawa mereka kembali ke Sion (tema ini sangat dominan dalam teks Yesaya). Ketika hari tersebut tiba, bangsa Israel akan bersuka (bdk. 1QH; 4QH ${ }^{\mathrm{a}, \mathrm{e}} ; 11 \mathrm{QMelchizedek;}$ dan sebagainya atas kemenangan dari Allah mereka).

Dalam tulisan-tulisannya, dan tidak berbeda dengan orangorang sebangsanya, Paulus kerap kali mengidentifikasi persoalan bangsa Israel sebagai masalah yang ditimbilkan oleh dosa mereka. Di dalam Efesus 6:12 Paulus menyatakan bahwa musuh utama dari umat Allah adalah kekuatan kegelapan, meliputi dosa-dosa mereka. Penindasan sesungguhnya bukanlah hasil penjajahan Roma, tetapi hidup di bawah kendali dosa. ${ }^{17}$ Dalam Roma 6, Paulus menjelaskan bahwa persoalan tersebut dapat diselesaikan dengan merujuk pada kematian Yesus di kayu salib (Roma 6:5-11). Menurutnya, kematian di atas kayu salib adalah kematian atas [kuasa] dosa (bdk.

\footnotetext{
${ }^{16}$ Bdk. N. T. Wright, Jesus and the victory of God (Minneapolis: Augsburg Fortress, 1996), 577; Wright, The New Testament, 277.

${ }^{17}$ James D. G. Dunn, The Theology of Paul the Apostle (Grand Rapids: William

B. Eerdmans, 1998), 211.
} 
1 Tesalonika 5:10-ditulis dalam konteks keselamatan eskatologis). Wright berpendapat bahwa peristiwa penyaliban sesungguhnya adalah sebuah deklarasi kemenangan atas dosa. ${ }^{18}$ Hal penting lainnya dalam Roma 6 adalah relasi antara peristiwa penyaliban dengan kebangkitan (Roma 6:4-5, 8-10). Kebangkitan dalam teks ini merujuk pada diwujudnyatakannya pengharapan eskatologis (bdk. Yehezkiel 37) melalui kematian (momen penyaliban) dan kebangkitan Yesus. Pokok penting ini selaras dengan pemikiran Paulus di 1 Korintus 15, di mana Paulus membahas dengan detil perihal kematian dan kebangkitan Yesus. Dalam 1 Korintus 15:3-4 Paulus mengungkapkan bahwa kematian Yesus adalah kematian bagi dosa umat Allah dan kebangkitan-Nya adalah kemenangan atas dosa. Menariknya, 1 Korintus 15 juga menunjukkan bahwa apa yang terjadi pada Yesus juga akan terjadi pada orang percaya (1 Korintus 15:22-23). ${ }^{19}$ Singkatnya, Paulus sepakat dengan orang sebangsanya bahwa persoalan mereka berhubungan erat dengan kuasa dosa. Namun tidak seperti mereka, Paulus percaya bahwa persoalan tersebut terselesaikan melalui momen penyaliban; pengharapan eskatologis terhadap Allah yang satu-satunya itu telah hadir dalam karya Yesus Kristus-sang Mesias.

Definisi kembali konsep eskatologi dalam pemikiran Paulus terlihat juga dalam teks Filipi 2:6-11. Ada beberapa hal penting dalam teks tersebut, seperti: Pertama, penggunaan kata $\alpha \rho \pi \alpha \gamma \mu$ ó $\varsigma$ dalam 2:6 mengindikasikan bahwa Yesus adalah Allah, sehingga beberapa ahli berpendapat bahwa konsep Christological Monotheism hadir di sini. $^{20}$ Kedua, Paulus menjelaskan

\footnotetext{
${ }^{18}$ Wright, Jesus, 594.

${ }^{19}$ Bdk. Cousar, The Cross, 98-9.

${ }^{20}$ R. W. Hoover, "The Harpagmos Enigma: A Philological Solution." in Harvard Theological Review 64 (1971), 95-119; C. F. D. Moule, "Further Reflection on Philippians 2.5-11", in Apostolic History and the Gospel, eds. W. W. Gasque and Ralph P. Martin (Exeter: Paternoster Press, 1970), 266-268, 271 6; N. T. Wright, The Climax of the Covenant (Edinburg: T\&T Clark, 1991), 6298.
} 
kemenangan yang Allah kerjakan di dalam Yesus melalui momen penyaliban. Ketiga, kemenangan di masa yang akan datang terealisasi melalui pujian dari setiap lidah dan tertekuknya semua lutut mengaku bahwa Yesus adalah Tuhan (Filipi 2:10-11). Dengan memerhatikan ketiga poin tersebut, pembaca dapat mendapatkan kesan bahwa Paulus sedang mendefinisikan kembali konsep kemenangan dari Allah berdasarkan tema Yesaya; Fil 2:9-11 jelas memiliki hubungan yang sangat dekat dengan Yesaya 45 maupun Yesaya 52-53. ${ }^{21}$ Dengan memanfaatkan kerangka dari Yesaya 52 dan 53, tampaknya Paulus sedang menjelaskan kedudukan salib dalam karya Allah yang menyelamatkan. Dalam Filipi 2, seorang pembaca dapat menemukan adanya relasi antara peristiwa penyaliban dan pujian hamba yang menderita dalam Yesaya 52 dan 53. Dalam konteks ini, penyaliban menjadi sebuah cara bagi Allah dalam membebaskan umat-Nya dari penindasan dan penderitaan (bdk. Yesaya 53). Penderitaan yang dialami oleh hamba Tuhan dalam Yesaya 52:13 menjadi pemantik bagi kemenangan yang Allah kerjakan-membawa kembali umat Allah ke Sion, sehingga segala lidah dan lutut dapat fokus menyembah Allah. Dengan memakai kerangka tersebut, pembaca dapat menghubungkan motif penderitaan Yesus di Filipi 2 (bahkan sampai mati di kayu salib!) dan hamba Tuhan menderita di teks Yesaya membawa dampak yang sama, yaitu kemenangan bagi umat Allah. Oleh karena itulah Paulus menasehatkan jemaat di Filipi untuk hidup dalam kemenangan (bdk. Filipi 2:4-5) di dalam Kristus.

\section{Definisi Kembali Shema}

Monoteisme Yahudi, seperti dijelaskan di atas, tidak dapat dipisahkan dari Shema. Shema, sebagaimana dicatatkan dalam

${ }^{21}$ Bauckham, Jesus and the God of Israel, 41-5; Francis Watson, "Mistranslation and the Death of Christ: Isaiah 53 LXX and its Pauline Reception." In Translating the New Testament (Grand Rapids: William B. Eerdmans, 2009), 246-8; cf. Michael J. Gorman, Cruciformity: Paul's narrative spirituality of the Cross (Grand Rapids: William B. Eerdmans, 2001), 90-1. 
Ulangan 6:4-9, dapat dimengerti sebagai pernyataan iman dan manifestasi dari iman monoteis bangsa Israel. Sebagai pernyataan iman, Shema yang diikrarkan dua kali sehari, berfungsi menegaskan keyakinan mereka kepada Allah yang esa. ${ }^{22}$ Selain itu, Shema juga berfungsi sebagai pengingat identitas bangsa Israel sebagai umat kepunyaan Allah. Menurut James Dunn, Shema memiliki hubungan yang erat dengan sepuluh hukum-tata cara hidup umat Allah. ${ }^{23}$ Sebagai manifestasi iman, Shema mengingatkan setiap orang Israel tentang hal paling mendasar dari kepercayaan mereka, yaitu kasih kepada Allah yang esa melampaui apapun sebagaimana dipraktekkan oleh Abraham dengan keluar dari keluarganya (bdk. Kejadian 12) dan ketika mempersembahkan Ishak (bdk. Kejadian 22). Fakta bahwa kasih merupakan elemen yang sangat penting dalam Shema tertulis dalam Ulangan 6:5. Dalam Ulangan 6:5 bangsa Israel diperintahkan untuk mengasihi Allah mereka dengan segenap hati, jiwa dan kekuatan mereka; singkatnya, dengan segenap eksistensi mereka. Melalui perintah tersebut, Shema berperan secara positif sebagai pengingat relasi mereka dengan Allah (bdk. Ulangan 6:24-25); secara negatif Shema berfungsi sebagai penolong untuk tidak terpengaruh oleh cara hidup para penyembah allah lain (bdk. Ulangan 6:13-14). Dengan demikian, bangsa Israel akan senantiasa menyadari identitas mereka, terutama setelah mereka masuk dalam tanah perjanjian (Ulangan 6:1-3) sebagaimana Allah janjikan kepada Abraham (Ulangan 6:10).

Di dalam tulisan-tulisan Paulus, Shema mendapatkan definisi ulang melalui lensa peristiwa penyaliban. Di dalam Shema (Ulangan 6:4-9), bangsa Israel diperintahkan untuk mengasihi Allah dengan segenap hati sebagai respons terhadap pembebasan

\footnotetext{
${ }^{22}$ Bdk. Tan Kim Huat, "Shema and Early Christianity", in Tyndale Bulletin 59.2, (Cambridge: Cambridge University, 2008), 181-2.

${ }^{23}$ James D. G. Dunn, Did the First Christians Worship Jesus? : The New

Testament Evidence (Louisville: Westminster John Knox Press, 2010), 62.
} 
yang Allah kerjakan bagi mereka. Di dalam tulisan Paulus, aksi pembebasan dari Allah itu sendiri dimengerti sebagai tindakan kasih Allah kepada umat-Nya. ${ }^{24}$ Melalui peristiwa penyaliban, Paulus melihat penindasan tidak hanya dalam bentuk fisik, tetapi juga spiritual. Dalam Roma 5:8, Paulus dengan jelas mengungkapkan bahwa peristiwa salib adalah ekspresi kasih Allah kepada umat-Nya (bdk. Roma 8:35). ${ }^{25}$ Dengan demikian, salib menjadi titik temu antara kasih Allah yang esa dan respons umat Allah yang terikat perjanjian dengan-Nya.

Selain menjadikan salib sebagai realisasi pembebasan dari Allah serta tantangan untuk mengasihi Allah sebagaimana dapat ditemukan dalam Shema, peristiwa penyaliban juga mendefinisikan kembali Shema sebagai identity marker bagi orang kristen mulamula. Salah satu teks terkenal untuk ini adalah 1 Korintus 8. Beberapa ahli melihat bahwa ada kemungkinan yang sangat besar Paulus menggemakan kembali Ulangan 6:4 di 1 Korintus 8:6. ${ }^{26}$

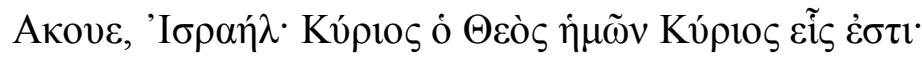

(Ulangan 6:4-LXX)

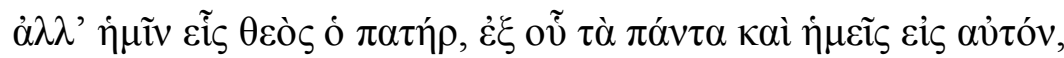

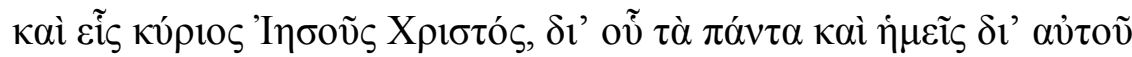

(1 Korintus 8:6)

Berdasarkan 1 Korintus 8:6, Paulus berusaha menjelaskan kedudukan Yesus dalam konteks monteisme Yahudi. Menurutnya,

\footnotetext{
${ }^{24}$ Bdk. Gorman, Cruciformity, 16-7, 161-3.

${ }^{25}$ Dunn, Paul, 230; Cousar, A Theology, 43-5.

${ }^{26}$ Lih. Wright, The Climax of Covenant, 128-30; Richard Bauckham, "The Shema and 1 Corinthians 8.6 again", in One God, One People, One Future: Essays In Honour Of N. T. Wright eds. John Anthony Dunne et al. (London: SPCK, 2018); ada juga ahli yang tidak setuju bahwa Paulus menggemakan Shema dalam 1 Korintus 8:6, seperti Thomas Gaston \& Andrew Perry, "Christological Monotheism: 1 Corinthians 8.6 and the Shema", in Horizons in Biblical Theology 39 (2017): 176-196.
} 
kehadiran Yesus harus dilihat sebagai penyingkapan figur кúpıৎ dalam Ulangan 6:4. Berdasarkan konteks logisnya, 1 Korintus 8:6 merupakan tanggapan Paulus terhadap isu makanan yang telah dipersembahkan kepada berhala. Dalam respons tersebut, Paulus dengan tegas menyerukan keyakinan monoteisnya kepada jemaat di Korintus. Baginya, hanya ada satu identitas ilahi (divine identity) (bdk. Ulangan 6:4). Keesaan tersebut termanifestasi dalam satu

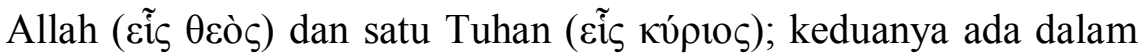
satu ketegori identitas yang sama, yaitu divine identity. Dalam hal ini, keyakinan terhadap Allah yang satu memberikan arahan untuk hidup etis secara bersama sebagai komunitas umat Allah. Oleh karena itulah, bagi Paulus, persoalan utama bukan lagi soal boleh atau tidaknya memakan persembahan kepada berhala, tetapi apakah aktivitas makan tersebut menjadi batu sandungan atau tidak. Dalam hal ini, ekspresi kasih kepada Allah diperluas dengan mengasihi sesama (bdk. Roma 15:3; Ibrani 12:2). ${ }^{27}$

\section{SIMPULAN}

Frasa kunci yang dapat merangkum seluruh isi artikel ini adalah "definisi kembali." Sebagaimana telah penulis ungkapkan pada bagian pendahuluan, frasa "definisi kembali" berusaha menjelaskan perubahan paradigma Paulus tentang covenant dan election, eskatologi, dan Shema dalam terang peristiwa penyaliban Yesus Kristus. Dalam terang salib, komunitas perjanjian tidak lagi didefinisikan secara lahiriah, tetapi berdasarkan relasi antara seseorang dengan Yesus yang telah tersalib itu. Dalam hal eskatologi, pengharapan Israel telah digenapi melalui pembebasan terhadap kuasa belenggu dosa dalam peristiwa penyaliban. Umat Allah merasakan bahwa Allah telah kembali ke Sion melalui

${ }^{27}$ Bdk. Romano Penna, Paul The Apostle: A Theological and Exegetical Study, vol. 2: Wisdom and Folly of The Cross (Collegeville: The Liturgical Press, 1996), 59-60. 
penyaliban Yesus di Sion. Berkaitan dengan Shema, peristiwa penyaliban merealisasikan dimensi kasih secara vertikal dan horizontal dalam hidup umat Allah.

Secara praktis, cara Paulus menafsirkan kembali Kitab Suci dan tradisi dalam terang salib seharusnya membuat gereja hari ini menyadari perannya sebagai umat Allah, Israel yang sejati. Pertama, gereja perlu menyadari bahwa ras bukan lagi kriteria untuk masuk menjadi anggota umat Allah. Perjanjian (covenant) antara Allah dan umat-Nya telah didefinisikan kembali melalui penyaliban, sehingga setiap orang dapat menjadi umat Allah dengan cara memiliki relasi dengan Yesus yang tersalibkan itu. Kedua, definisi kembali kemenangan yang Allah seharusnya memberikan penguatan kepada setiap jemaat untuk menjalani hidup yang menang terhadap kuasa dosa, seperti persoalan korupsi, percabulan, kecanduan terhadap obat-obatan dan lain sebagainya. Terakhir, definisi kembali terhadap Shema dapat memberikan inspirasi bahwa pengakuan iman tentang keesaan Allah seharusnya diwujudnyatakan secara etis dalam keseharian dalam komunitas orang percaya.

\section{DAFTAR RUJUKAN}

Bauckham, Richard. "The Shema and 1 Corinthians 8.6 again", in One God, One People, One Future: Essays In Honour Of $N$. T. Wright eds. John Anthony Dunne et al. London: SPCK, 2018.

Bauckham, Richard. Jesus and the God of Israel. Grand Rapids: William B. Eerdmans Publishing, 2008.

Cousar, Charles B. A Theology of The Cross: The Death of Jesus in The Pauline Letters. Minneapolis: Fortress, 1990. 
Dunn, James D. G. Did the First Christians Worship Jesus? : The New Testament Evidence. Louisville: Westminster John Knox Press, 2010.

Dunn, James D. G. The Theology of Paul the Apostle. Grand Rapids: Wm B Eerdmans, 1998.

Gaston, Thomas. \& Perry, Andrew. "Christological Monotheism: 1 Cor 8.6 and the Shema", in Horizons in Biblical Theology 39 (2017) 176-196.

Gorman, Michael J. Cruciformity: Paul's narrative spirituality of the Cross. Grand Rapids: William B. Eerdmans, 2001.

Hoover,R. W. "The Harpagmos Enigma: A Philological Solution", in Harvard Theological Review 64 (1971).

Hurtado, Larry "Paul's Christology." in The Cambridge companion to St. PaUlangan ed. James Dunn. Cambridge: Cambridge University Press, 2003.

Hurtado, Larry. How on Earth did Jesus Become a God?: Historical Questions About Earliest Devotion to Jesus. Grand Rapids: William B. Eerdmans Publishing, 2005.

Hurtado, Larry. Lord Jesus Christ: Devotion to Jesus in Earliest Christianity. Grand Rapids: William B. Eerdmans, 2003.

Hurtado, Larry. One God, one Lord: Early Christian Devotion and Ancient Jewish Monotheism. London: SCM Press, 1988.

Moule, C. F. D. "Further Reflection on Philippians 2.5-11", in Apostolic History and the Gospel, eds. W. W. Gasque and Ralph P. Martin. Exeter: Paternoster Press, 1970.

Nelson, R. David "The Word of the Cross and Christian Theology: Paul's Theological Temperament for Today," Theology Today, Vol. 75 (1), 2018. 
Penna, Romano. Paul The Apostle: A Theological and Exegetical Study, vol. 2: Wisdom and Folly of The Cross. Collegeville: The Liturgical Press, 1996.

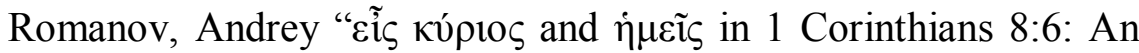
Investigation of the First Person Plural in Light of the Lordship of Jesus Christ", in Neotestamentica, Vol. 49, (1), 2015.

Smith, Brandon D. "What Christ Does, God Does: Surveying Recent Scholarship on Christological Monotheism," in Currents in Biblical Research, Vol. 17(2), 2019.

Tan Kim Huat, "Shema and Early Christianity" in Tyndale Bulletin 59.2, Cambridge: Cambridge University, 2008.

Watson, Francis. "Mistranslation and the Death of Christ: Isaiah 53 LXX and its Pauline Reception." In Translating the New Testament. Grand Rapids: William B. Eerdmans, 2009).

Watson, Francis. Paul and the Hermeneutics of Faith 2nd Ed. London: T \& T Clark 2015.

Wright, N. T. Jesus and the victory of God. Minneapolis: Augsburg Fortress, 1996.

Wright, N. T. Paul and the Faithfulness of God. Minneapolis: Fortress Press, 2013.

Wright, N. T. Paul in Fresh Perspective. Minneapolis: Fortress Press, 2009.

Wright, N. T. The Climax of the Covenant. Edinburg: T\&T Clark, 1991.

Wright, N. T. The New Testament and The People of God. London: SPCK, 1992. 